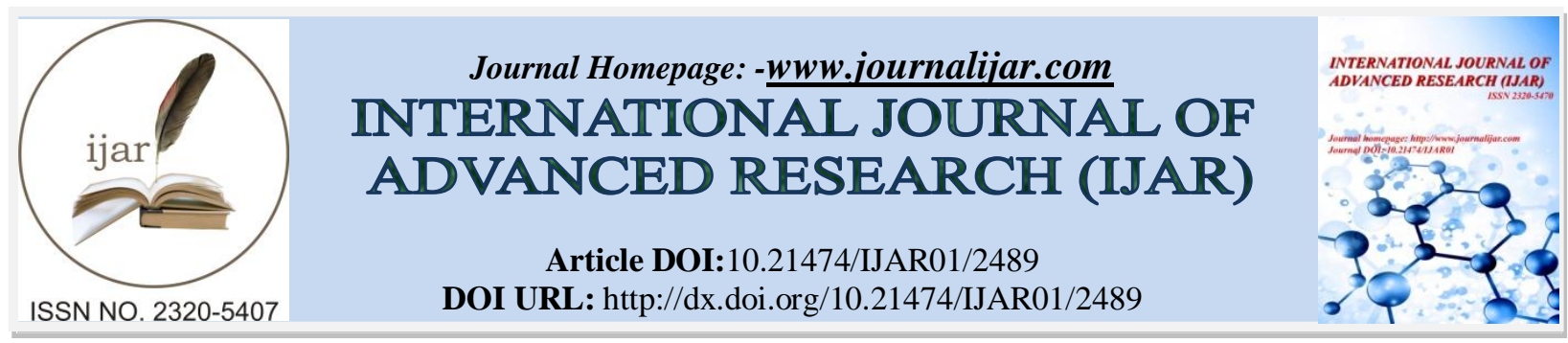

RESEARCH ARTICLE

\title{
ANALYSIS OF FOREIGN DIRECT INVESTMENT INFLOW TRENDS IN THE MANUFACTURING SECTOR OF INDIA
}

Chintagada Ramjee

Research scholar in the School of Economics, University of Hyderabad, Telangana.

\section{Manuscript Info}

Manuscript History

Received: 23 October 2016

Final Accepted: 21 November 2016

Published: December 2016

\section{Abstract}

This paper analyses the trends in the Foreign Direct Investment (FDI) inflows into various sub-sectors of the manufacturing sector of India. It also brings out the chronological sequence of opening up of various sectors of the Indian economy for FDI. The manufacturing sector attracted significant amount of FDI in the past fifteen years of which a major chunk accrued to technology intensive sectors, while the labour intensive ones received negligible inflows. Labour intensive sectors, especially, food processing sector, leather sector and textile sector has a huge potential for growth and contribution to the overall health of the manufacturing sector. These sectors also have the maximum capability to generate employment opportunities. Active government intervention through supportive policies is imperative in this regard.

Copy Right, IJAR, 2016,. All rights reserved.

\section{Introduction:-}

Foreign Direct Investment (FDI) has been a subject matter of debate for quite some time since the emergence of multinational corporations. It has been debated extensively for its perceived benefits to both the home country, as well as the host country. In India, though foreign investments have been taken up from the time of the British colonial rule, the topic of FDI gained prominence only post the 1991 reforms- it has taken a vital position in the economic policies of the successive governments since then. Its role has become so evidently important with the fact that the current government which staunchly opposed the entry of FDI into our economy in the decades of 2000s, is now aggressively pursuing this policy and has now opened up almost the entire economy to FDI barring a very few sectors. Even the so-called most sensitive sectors like defense and railways have also been opened up for FDI where the foreign entities can own a majority stake. Now, India has become "the most open economy in the world for FDI." The Make in India campaign initiated by the current government already resulted in FDI inflows of 7 billion dollars over the period October 2015 to February 2016, which is a 45\% increase over the same period the previous year. In this context, it is imperative to analyze the evolution of the FDI policy of India and the trends in the FDI inflows into the manufacturing sector.

In this paper, the manufacturing sector has been divided into various sub-sectors namely, engineering goods sector (comprising of computer software and hardware, electronics and electrical equipment, heavy machinery, medical and laboratory instruments, etc.), chemicals sector (comprising chemicals, drugs and pharmaceuticals, rubber, glass,etc.), food processing sector, leather sector and textiles sector. These sub-sectors account for 85 to $90 \%$ of FDI inflows as well as employment of the manufacturing sector. The trends in the FDI inflows of the sub-sectors have been explained and also represented through graphs. The time period chosen for the purpose of the study is 15 years starting from 1999-2000 upto 2013-2014. 


\section{Review of Literature:-}

The literature on FDI revolves around two basic questions. One, "why firms resort to FDI in other countries"?and the other, "why countries seek to attract FDI"? Boddewyn(1985) seeks to answer the first question by proposing three explanatory categories around which the theories of FDI revolve. They are 1)Conditions, 2)Motivations, and 3)Precipitating factors or circumstances. Conditions are those factors which influence the behavior of the firms and countries, like firm size, size of market, cost of factors of production, product diversification, etc. Motivations refer to the factors which motivate firms to invest in foreign countries, like profitability, least cost opportunities, monopoly profits, etc. precipitating factors include government initiatives like tax holidays, subsidies, monopoly grants, etc. Apart from these factors, sometimes the overseas moves of the competitors forces the firm to invest abroad in order to protect its global market share. The theories of FDI emphasize on one or more of the above explanatory categories. Among the theories of international trade, Vernon's(1966) product-life-cycle theory tried to explain why FDI occurs. He explained that the threat of losing markets in the maturity stage and the imperative of cost minimization forces a firm to involve in investments abroad. Hymer (1960) in his Industrial organization theory, propounded that structural imperfections in the market, like patent-protected superior technology, economies of scale, product diversification, access to cheaper finance, etc. gives ownership advantages to firm which leads to the firm in investing in other countries. Kindleberger(1969) later expanded Hymer's theory and added 'monopoly profits' as another motivation for firms to involve in FDI. Coase (1937) and Buckley and Casson(1976) in their 'market internalization theory' propounded that FDI occurs due to transaction-cost imperfections that lead to replacement of 'external' markets by 'internal' markets. Dunning(1977, 1979 \&1993) proposed his eclectic paradigm or the OLI paradigm by consolidating the 'Industrial organization theory' and 'Market Internalization theory' along with another factor which he termed 'Locational Advantages'. He concluded that all the three conditions viz; ownership advantages, internalization advantages, and locational advantages, must be fulfilled if a firm has to resort to FDI.

On the second question of "why countries seek FDI"? economists have done extensive case studies and proposed many benefits that accrue to the host countries. Aaron(1999) in his study found that FDI helped in growth of the economy and reduction in poverty. Generation of new employment opportunities(Jenkins and Thomas, 2002), higher wages of employees in FDI enabled firms compared to domestic firms(Pradhan, Abraham, and Sahoo, 2004), transfer of superior technology leading to productivity increases (Ghosh and Roy, 2015), forward and backward linkages leading to generation of direct and indirect jobs and growth in ancillary industries, etc. are other benefits that are found out to be occurring due to FDI in the host countries.

\section{FDI: Definition and Policy Evolution:- Definition:-}

The Department of Industrial Policy \&Promotion defines Foreign Direct Investment as “any investment by a nonresident entity or person resident outside India in the capital of an Indian company under schedule of the Foreign Exchange Management Act (FEMA), 1999 and FEMA regulations, 2000”.

\section{FDI Routes:-}

Investments can be made by non-residents in the equity shares/fully, compulsorily and mandatorily convertible debentures/fully, compulsorily and mandatorily convertible preference shares of an Indian company through 2 different routes

1) Automatic route: the Non-resident entity or person does not require any approval from government of India for investment.

2) FIPB route: proposals for the foreign investment are considered by the Foreign Investment Promotion Board (FIPB). Based on the recommendations of the FIPB, the finance ministers considers the proposals for FDI equity of Rs.5000 crores and below, and the Cabinet Committee on Economic Affairs considers the proposals for FDI of above Rs.5000 crores.

\section{FDI Policy Evolution:-}

FDI policy in India has become increasingly liberal over the past half a century. In the first phase between 1969 and 1991, the Monopoly and Restricted Trade Practices (MRTP) Act and the Foreign Exchange Regulation Act (FERA) restricted the operation of the foreign firms in terms of size, type of products, equity participation, etc. In the second phase during 1991 to 2000, FDI policy was substantially liberalized by allowing $51 \%$ foreign participation through automatic route in 35 high priority industries. During this period FIPB was constituted to consider FDI under the 
government route. In the third phase which is 2001 onwards, the FDI policy has been substantially liberalized with a negative list approach with all other activities permitted through the automatic route and substantial relaxation in terms of equity caps has also been made. Now, for most of the sectors, foreign technological collaboration through automatic route has surpassed that through approval route.

In 1991, the New Industrial Policy as a part of the union budget led to a substantive opening up of the Indian economy. FDI up to $51 \%$ was opened up in the 47 high-priority sectors, including software sector, export trading firms, hotels and tourism businesses, with a condition that capital goods imports be financed by foreign equity. FIPB was setup in the PMO to vet FDI proposals with a finance minister-headed panel deciding on investments taking a call on FDI of over Rs.300 crores.In 1992, FDI on software was also put on automatic route. Use of foreign brand names was allowed. Dividend balancing norms for FDI backed firms, linking dividend payments to export income, were scrapped for all but consumer goods firms.In 1994, the FDI in drugs and pharmaceutical sector of up to 51\% was brought under automatic route.In 1996, the FIPB was transferred to DIPP from Prime Minister's Office. Approvals of up to Rs.600 crores was considered by the minister of commerce and industry, and the FDI approvals of more than Rs.600 crores was considered by the Cabinet committee on economic affairs. The condition linking import of capital goods to foreign equity investments was scrapped.In 1998, the mobile telephony using satellite sector was opened up for 49\% FDI.In 1999, the FDI cap for the sectors of construction of highways, toll roads and ports, was raised from $74 \%$ to $100 \%$. Also, the timeline for considering FDI proposals was slashed from 6 weeks to 30 days.In 2000, FDI norms were eased to allow FDI of 100\% in the Non-banking financial companies and insurance sector was opened up for FDI of up to 26\%.In 2001, drugs and pharmaceutical sector, airports, hotel, tourism businesses were opened up for FDI of $100 \%$. Select sectors of telecom industry were opened up for $74 \%$ FDI. Banking sector was opened up for 49\% FDI. And, the defense sector was opened up for 26\% FDI. In 2004, $100 \%$ FDI was allowed in petroleum product marketing, oil exploration and natural gas pipe lines. $74 \%$ FDI was allowed in private banking sector.In 2005, townships were opened up for 100\% FDI. Radio broadcasting was opened up for the first time for FDI of up to 20\%. The entire telecom sector was opened up for 74\% FDI.In 2006, single brand retailing was opened up for 51\% FDI.In 2009, 100 FDI was allowed in fax publication of foreign newspapers, and 26\% FDI was allowed in publication of Indian version of foreign publications.In 2011, 100\% FDI was allowed in brownfield pharmaceuticals projects which were hitherto open only for green-field projects.In 2012 , single brand retail was opened up for $100 \%$ FDI. Multi-brand retailing was opened up for 51\% FDI. Aviation companies and power exchanges were opened up for 49\% FDI. Tele-sports and mobile TV were opened up for $74 \%$ FDI. In 2014, defense sector was opened up for 49\% FDI, and some aspects of rail infrastructure were opened up for $100 \%$ FDI.In the latest announcement of FDI policy, the government stated that the changes in FDI policy were intended to "ease, rationalize and simplify the process of foreign investments in the country and to put more and more FDI proposals on automatic route instead of government approval route where time and energy of the investors is wasted." The consolidated FDI policy circular stated that 'It is the intent and objective of the government to attract and promote foreign direct investment in order to supplement domestic capital, technology and skills, for accelerated growth. Foreign direct investment has the connotation of establishing a 'lasting interest' in an enterprise that is resident in an economy other than that of the investor." In consonance with the changed FDI policy, radical amendments in few sectors have been made to encourage FDI inflows. Accordingly, in 2015, insurance and pension sectors were opened up for 49\% FDI.Recently, in 2016, 100\% FDI was allowed in trading including e-commerce, defense, tele-sports, mobile TV, DTH and Brownfield aviation projects. Private security agencies and animal husbandry areas were opened up for $74 \%$ FDI.

FDI restricted areas are lottery, gambling, railway operations, atomic energy, real estate investment trusts. FDI Policy: Critical View:-

Many economists argue that FDI has not helped Indian economy as was expected when the economy was opened up. The growth rate of India, they claim was spurred mostly by Indian domestic resources and FDI had little role.Also, there are costs of FDI that India had to bear. An analysis of official statistics of RBI shows that though India has seen steep FDI inflows in the past few years, the costs stemming from outflows on account of operation of foreign companies have outweighed the inflows. It has been reported that between 2009-0 and 2014-15, outflows due to repatriations, dividends and payments for technology have led to a major foreign exchange drain which accounts to nearly one-and -half of the equity inflows during the same period.Also, the report says that subsidiaries of foreign companies operating in India ran negative trade balances in almost all manufacturing subsectors. Together with remittances and other payments, foreign subsidiaries in most sectors drew out surpluses which are quite large when compare with the capital the foreign companies are bringing in. The criticism is that the government of India did not make effective policy to check these costs of FDI.Another argument on criticism of the FDI policy was that 
the policy remains uncertain on tax liabilities of the foreign companies. Numerous tax liability disputes have arisen since FDI started coming in. The legal and policy uncertainties with FDI still remain a major huddle for foreign companies investing in India.

\section{FDI Inflows into the Indian Manufacturing:- Engineering goods sector:-}

The engineering goods sector of India includes many major sub-sectors of which the prominent ones are electronics and computer hardware and software. Post the 1991 reforms electronics and computer hardware and software markets have driven economy in a high growth trajectory. India being a huge market for the finished products of these industries, and a source of cheap labour for the foreign entities has attracted the greatest portion of foreign investments among the manufacturing sub-sectors. Many foreign companies established their business process outsourcing centers in India which helped them in cost-cutting and also generated employment opportunities for the labour force of the country. The engineering goods sector attracted the maximum amount of foreign direct investment among the sub-sectors within the manufacturing sector. Foreign direct investment into this sector reached its peak in the year 2011-2012 with an amount of US dollars 5242 million. The highest growth rate of FDI inflows into this sector occurred in 2005-06 with 83 percent growth from its previous year, and the lowest growth is a negative growth rate in the year 2003-04 which is -23 percent. The compound annual growth rate for the FDI inflows in to the engineering sector between 1999 and 2014 is 14.9 percent.

\section{Chemicals and related products:-}

The Indian chemicals manufacturing sector has been attracting a major portion of the foreign direct investment flowing into the total manufacturing sector for quite some time now. The huge population of India makes it a major market for chemical products. The huge demand for chemical products and drugs and pharmaceuticals is helping the industry to boom. Apart from the above factors the presence of traditional systems of medicine and medicinal herbs also makes the country attract huge investments. The foreign investors are investing in drugs and pharmaceuticals heavily because of the opportunity that the generic drug market provides in India. Also, the labour costs are quite low compared to other countries in production of chemical and drug products. The chemicals sector was the second most attractive destination sector for foreign direct investment within the manufacturing sector with a peak inflow of us dollars 7753.1 million in 2011-12. The annual growth rate of 299 percent achieved in 2004-05 was the highest growth rate of FDI inflows in to this sector compared to the previous year. The lowest growth rate was a negative growth rate of 68.1 percent in the year 2012-13. The compound annual growth rate of FDI inflows for the entire chemicals sector in the time period 1999-2014 is 19.7 percent.

\section{Food processing sector:-}

The food processing sector of India is of special significance for the country because of its huge its huge potential in production of fruits and vegetables, and more importantly, its capability to engage large amount of labour force because of its labour intensive nature. The industry is at a nascent stage currently and investments in it could reap enormous benefits to the economy. A report by the ministry of food processing industries stated that a huge portion of fruits and vegetables produced in the country goes waste because the industry is not technologically advanced. The absence of infrastructural facilities like cold storages, food processing factories, etc., leads to this wastage of food produce. Tapping this potential of the industry by investing in infrastructure could help India become completely Independent of food imports, and in fact turn it into a major food market for the global economy. The food processing sector was the next most attractive destination sector for foreign direct investment within the manufacturing sector with a peak inflow of us dollars 3982million in 2013-14. The annual growth rate of 892 percent achieved in 2013-14 was the highest growth rate of FDI inflows in to this sector compared to the previous year. The lowest growth rate was a negative growth rate of -83 percent in the year 2002-03. The compound annual growth rate of FDI inflows for the entire chemicals sector in the time period 1999-2014 is 26.2 percent. The sudden peak in the FDI especially in the year 2013-14 was a result of the government announcing a policy decision of establishing Mega food parks in the country to give a major boost to the food processing industry.

\section{Leather and leather products:-}

The leather sector which is predominantly a labour intensive sector has been neglected by the policy makers with literally no significant policy brought out to attract more FDI. The importance of attracting more investment lies in its capability to employ vast amount of labour force which is lying idle in the country. Leather sector has ended up as the least attractive destination for the foreign investors with inflows of meager amounts in the successive years. The compound annual growth rate of FDI inflows into this sector is just 1.3 percent with a peak inflow amount of 
46.7 US million dollars in 2012-13. The highest growth rate in FDI inflows was in 2003-04 which was 1392 percent, and the lowest was a negative of -93.7 percent in 2004-05.

\section{Textile Sector:-}

The textile sector of India is also a labour intensive sector which is a lifeline for large number of families in India. The development of this sector is of prime importance in generation of employment opportunities. Textile industry of industry has suffered due to fluctuations in demand due to occurrence of economic crisis in western markets which are prime sources of demand for the Indian textile industry. Unfortunately, the textile sector could attract only a little less than moderate FDI inflows in the successive years. The compound annual growth rate of FDI inflows into this sector is 22.2 with a peak inflow amount of 199.4 US million dollars in 2013-14. The highest growth rate in FDI inflows was in 2002-03 which was 889 percent and the lowest was a negative of -68.7 percent in 2003-04.

Figure No.1

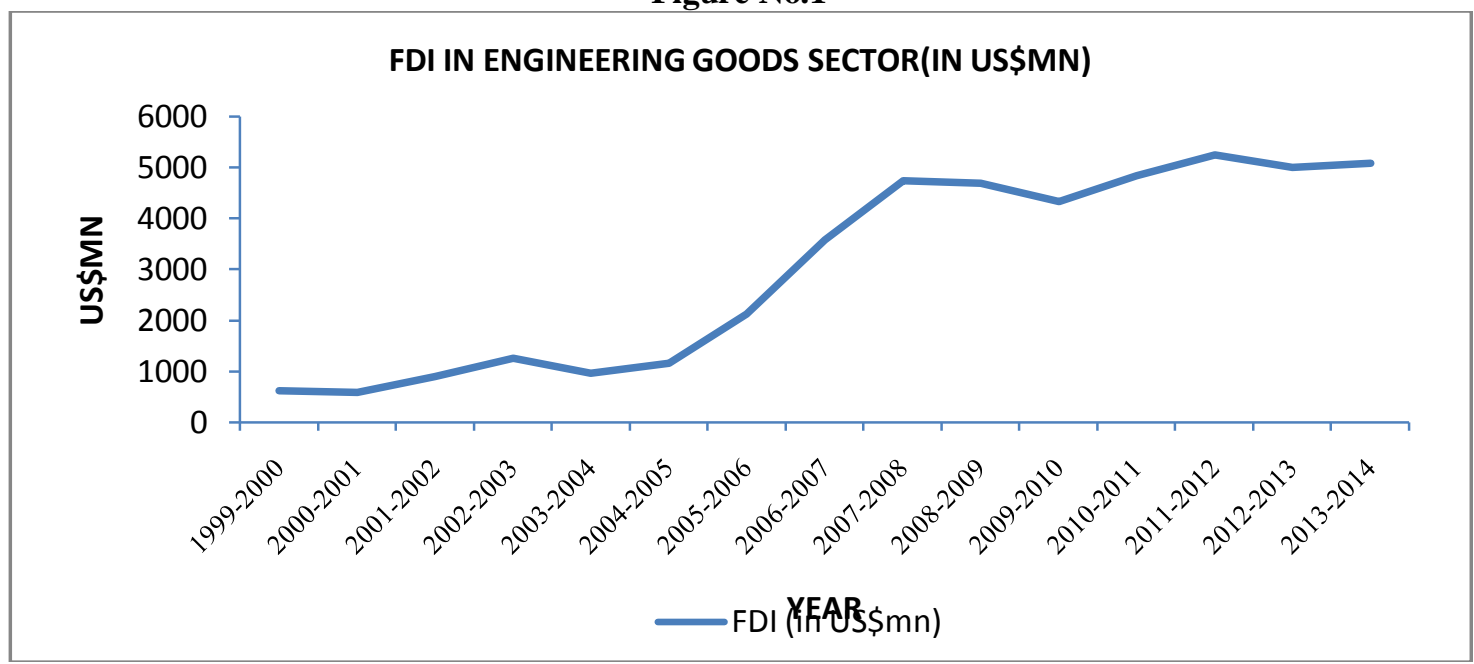

*Source: DIPP, Ministry of Commerce\&Industry, Govt. of India.

Figure no. 2

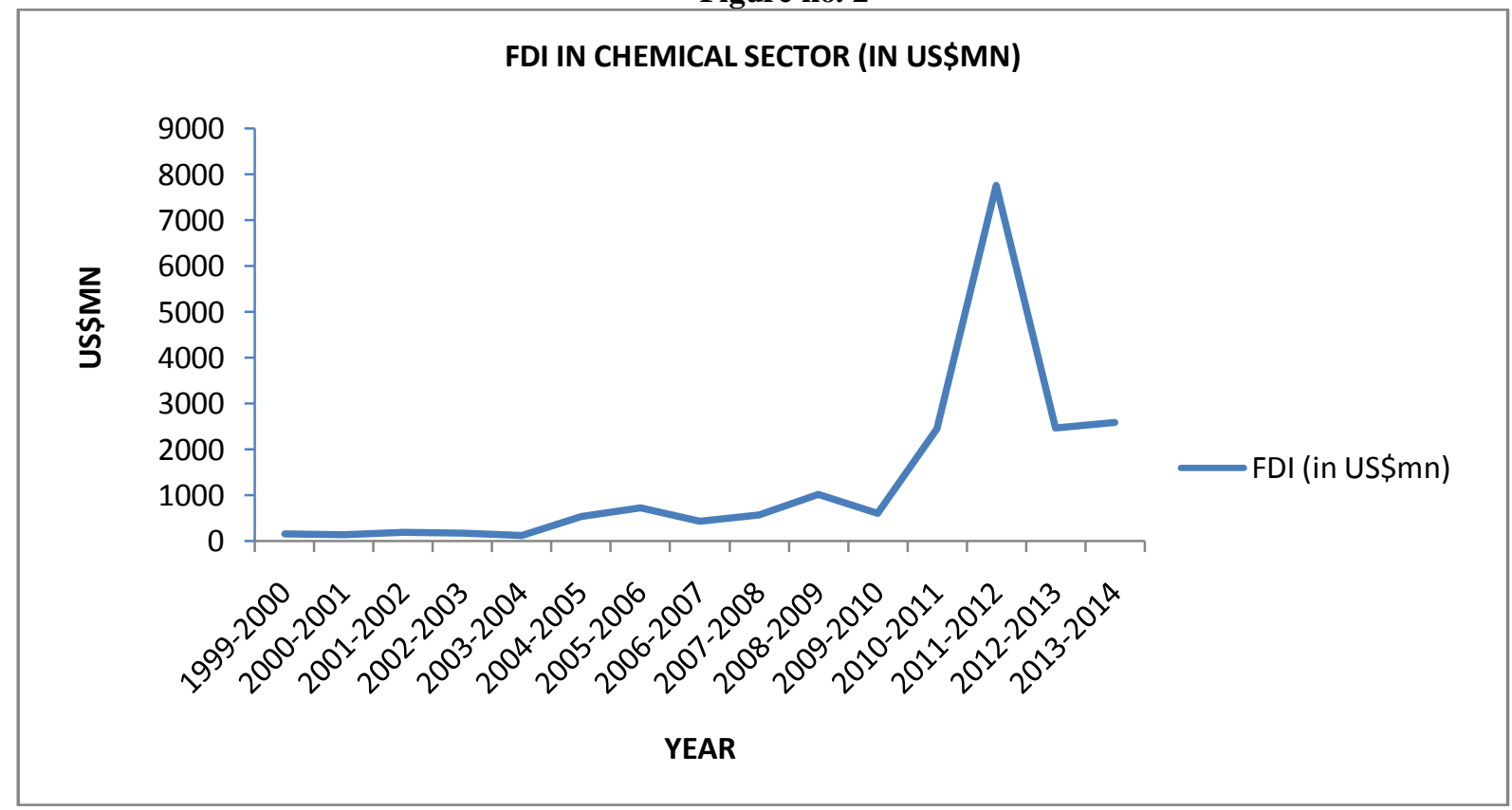

*Source: DIPP, Ministry of Commerce\&Industry, Govt. of India. 
Figure no. 3

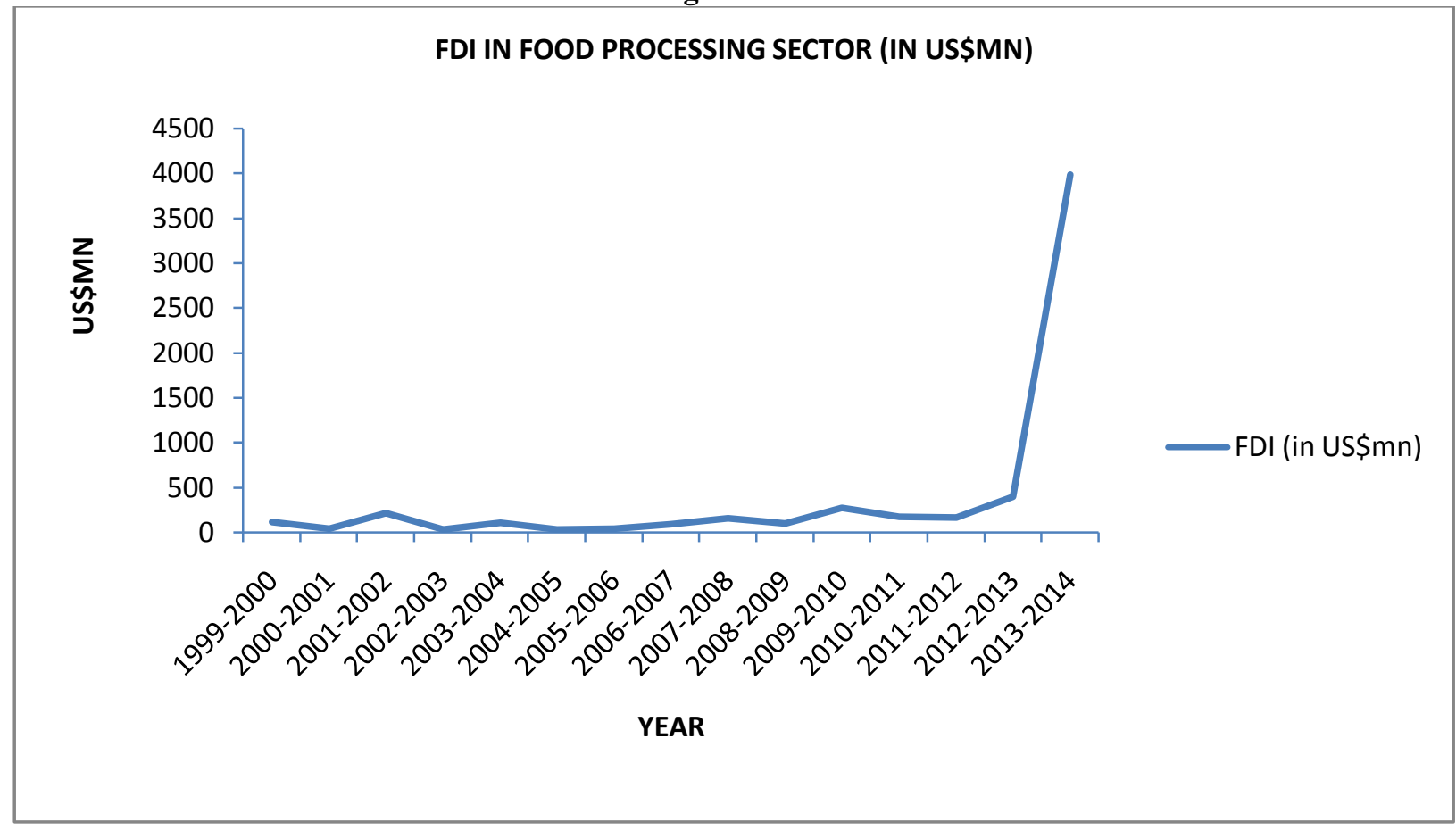

*Source: DIPP, Ministry of Commerce\&Industry, Govt. of India.

Figure no. 4

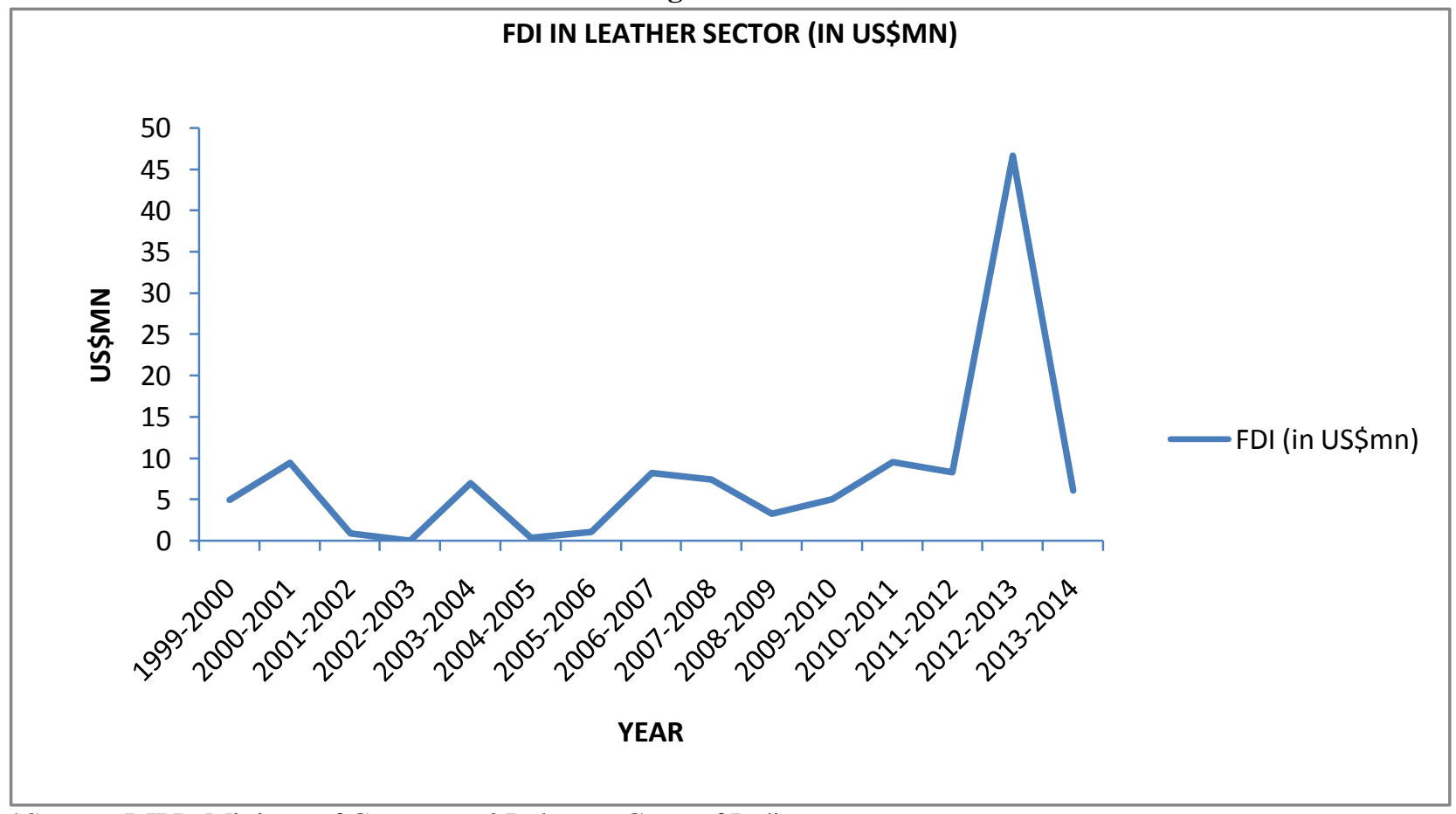

*Source: DIPP, Ministry of Commerce\&Industry, Govt. of India. 
Figure no. 5

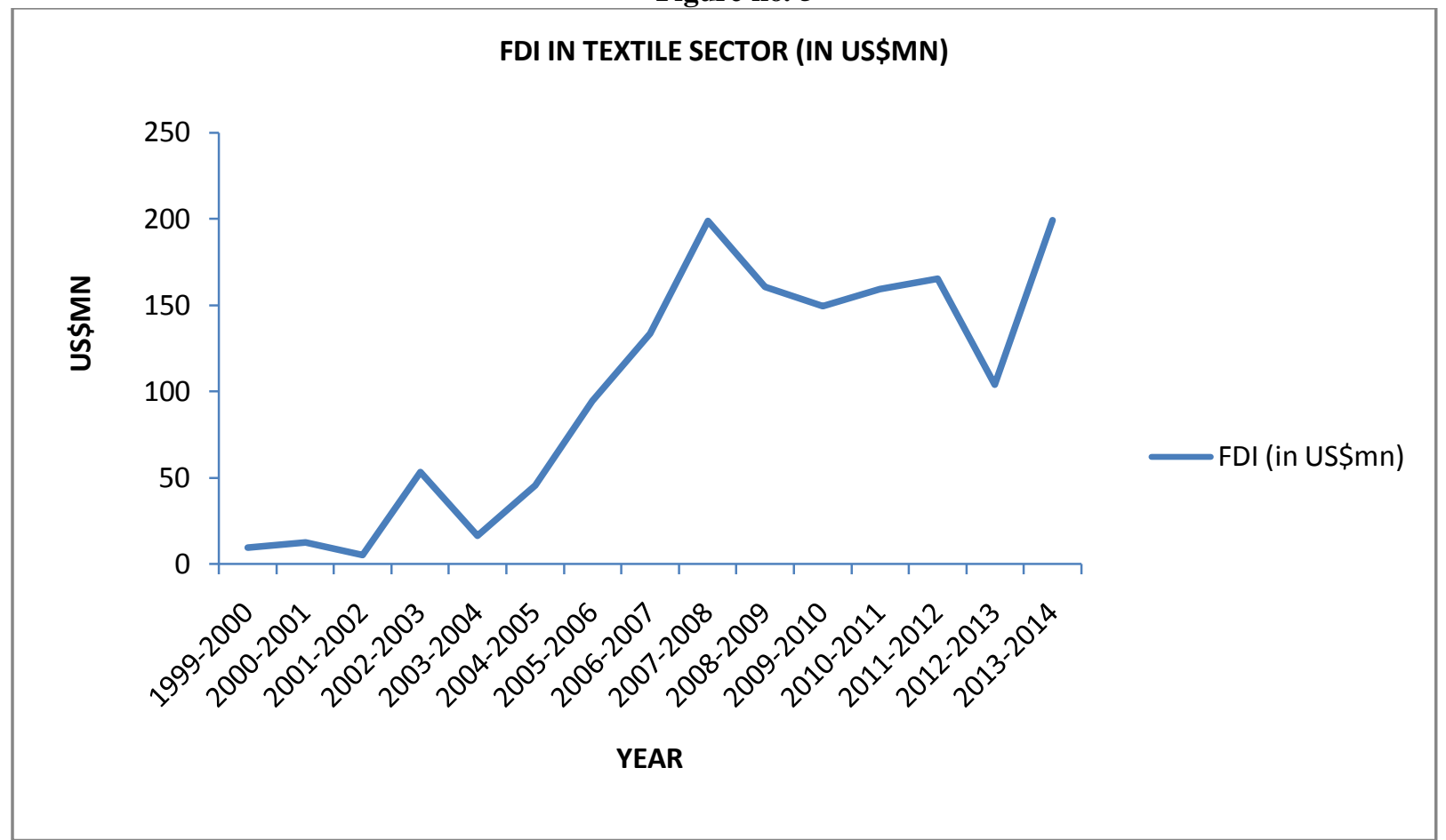

*Source: DIPP, Ministry of Commerce\&Industry, Govt. of India.

Average Annual Growth Rate of FDI in Indian Manufacturing(1999-2014):

Table: - Average Annual Growth Rates of FDI

\begin{tabular}{|l|c|}
\hline \multicolumn{1}{|c|}{ Sector } & $\begin{array}{c}\text { FDI } \\
\text { (AAGR) }\end{array}$ \\
\hline Engineering & 0.014 \\
\hline Chemicals & 0.192 \\
\hline Textiles & 0.215 \\
\hline Food Processing & 0.249 \\
\hline Leather & 0.017 \\
\hline
\end{tabular}

The average annual growth rate of FDI inflows in the past fifteen years between 1999 and 2014 was faster in textiles, food processing and chemicals sector compared to the engineering and leather sectors. However it has to be noted that the higher annual growth rates of food processing and chemicals was a result of heavy inflows of FDI in the last three years only.

\section{Findings of the Study:-}

1. The FDI policy of India has become increasingly liberalized over the past half a century. Successive governments have opened up various sectors for FDI gradually and strategically. At present, almost all the sectors are open to FDI where foreign entities can own a majority stake. This policy has resulted in gradual, but significant FDI inflows into Indian manufacturing sector which is starved of capital.

2. The FDI policy has been criticized for its inability to address the problem of outflows in the form of repatriations, dividends, etc. which is greater than the FDI inflows in recent years. It is also criticized for the legal and policy uncertainties on the part of government that is a major hurdle for FDI brining companies.

3. The inflows of FDI into India between 1991 and 2000 were not very significant. This shows that the opening up of the economy through the big bang reforms of 1991 did not result in a sudden response in terms of international capital inflows in to the economy. The foreign investment inflows picked up gradually with time and the decade of 2000 was the boom period for India in term of FDI inflows. The FDI inflows increased significantly in this decade with peak in the year 2011-12.

4. However, foreign direct investment inflows into Indian manufacturing sector in the time period 1999-2014 reveals clearly that most of the FDI that has come in to the manufacturing sector has been in to the engineering 
goods and the chemical sectors. These two sectors being highly technology intensive sectors with a greater profit margin and a growing market have attracted the most FDI. The other sectors namely, textiles, food processing and leather could not attract much FDI. These sectors being more labour intensive and lesser profit margins compared to the technology intensive sectors failed in garnering a major share of the FDI inflows. This phenomenon clearly shows us that the FDI inflows into the Indian manufacturing sector has been primarily efficiency seeking, market driven and export oriented. The FDI inflows have been higher in those sectors where market imperfections gave an opportunity to exploit ownership advantages of FDI making companies to increase their margins and hence profits.

\section{Conclusion:-}

Firms resort to FDI depending mainly upon ownership, internalization and locational advantages. Countries seek FDI mainly because of their perceived benefits of FDI's contribution to growth, employment, export performance, technology transfer and productivity increases. Indian manufacturing since the 1991 reforms has been gradually opened up for FDI. The manufacturing sector attracted significant amount of FDI of which major portion accrued to technology intensive sectors rather than labour intensive sectors. The criticism of FDI policy of India revolves around the extensive capital outflows in recent times, legal and policy uncertainties of the government.

\section{References:-}

1. Aaron (1999). "The contribution of FDI to poverty alleviation", paper presented in the seminar of foreign investment advisory service, Singapore.

2. Boddewyn, J (1985). "Theories of Foreign direct investment and divestment:Aclassificatory note", Management International Review, Germany,25(1):57-65.

3. Buckley, P.J and M.Casson (1976). "The future of MNEs", MacMillan,London.

4. Coase, R.H (1937). "The nature of the firm", Economica, Vol.4, No.16.

5. Dunning, J.H (1977,1979\& 1993). "Trade location of economic activity and the MNE:A search of an Eclectic approach", 1977.

6. "Explaining changing patterns of international production in defense of the eclectic theory", Oxford bulletin of Economics and statistics, Vol.41,1979.

7. "The globalization of business", Routledge, London, 1993.

8. Jenkins, c and L.Thomas(2002). "FDI in southern Africa:determinants, characteristics andimplications for economic growth and poverty alleviation", October 2002.

9. Kindleberger, C.P (1969). “American business abroad”, Yale University Press, New Haven.

10. Hymer, S.H (1976). "The international operation of national firms:A study of FDI", Cambridge, US.

11. Vernon, R (1966). "International investment and international trade in the product cycle", quarterly journal of economics, vol.80, No.2.

12. Pradhan, J.P, V.Abraham and M.Sahoo (2004). "Foreign direct investment and labour:The case of Indian manufacturing", labour and development, vol.10, No.1, PP. 58-79.

13. Ghosh, M and S.S.Roy (2015). "FDI,technological choices and spillovers in an emerging marketeconomy:A study of Indian manufacturing industries".

14. Various Newsletters of the Department of Industrial Policy and Promotion, Ministry of Commerce and Industry, Government of India.

15. Various FDI policy circulars of Ministry of Commerce and Industry, Government of India. 